\title{
The balanced induction of K-ras codon 12 and 13 mutations in mucosa differs from their ratio in neoplastic tissues
}

\author{
MAGDALENA C. KRAUS ${ }^{1}$, MATTHIAS H. SEELIG ${ }^{2}$, ULRICH LINNEMANN $^{3}$ and MARTIN R. BERGER ${ }^{1}$ \\ ${ }^{1}$ Toxicology and Chemotherapy Unit, German Cancer Research Center, Im Neuenheimer Feld 280, D-69120 Heidelberg; \\ ${ }^{2}$ St. Josef-Hospital Bochum, Surgical Clinic I of the Ruhr-University Bochum, Gudrunstr. 56, D-44791 Bochum; \\ ${ }^{3}$ Department of Visceral, Thoracic and Endocrine Surgery, Municipal Hospital Nürnberg Nord, \\ Professor Ernst-Nathan Strasse 1, D-90419 Nürnberg, Germany
}

Received March 20, 2006; Accepted May 22, 2006

\begin{abstract}
The aim of this study was to compare the ratio of K-ras codon 12 and 13 mutations in various tissues of colorectal cancer patients. Multiple samples of inconspicuous mucosa and a sample of carcinoma tissue were taken from 36 colorectal cancer patients (group I) and these results were compared with those from polyp and carcinoma tissues of another 48 colorectal cancer patients (group II). A polymerase chain reaction-restriction fragment length polymorphism (PCR-RFLP) assay was used to detect the respective point mutations. The results of this assay were complemented by sequencing the K-ras mutations. In mucosa tissue, the ratio of codon 12 and 13 mutations was nearly equal (0.9:1) whereas the respective ratio in tumour tissue showed a strong preponderance of K-ras codon 12 mutations (14:1, p=0.004). In polyp tissue of patients from group II, the ratio was $2.7: 1$ and that in carcinomas was 19:1 $(\mathrm{p}=0.053)$. The prevalence of both types of mutation was $14.6 \%$ in all mucosa samples, corresponding to $30.6 \%$ of group I patients. The K-ras mutation rate in carcinoma tissue of the same patients was $38.9 \%$. Similarly, $33.4 \%$ of all polyp and $41.7 \%$ of all carcinoma samples from group II harboured K-ras codon 12 and/or 13 mutations. Sequencing confirmed 59 of $60 \mathrm{~K}$-ras codon 12 mutations, but due to the detection limit for sequencing $\left(1: 10^{4}\right)$ only 10 of $20 \mathrm{~K}$-ras codon 13 mutations were confirmed. It is concluded that after balanced induction K-ras codon 12 mutations increase in frequency relative to K-ras codon 13 mutations during tumour progression.
\end{abstract}

Correspondence to: Professor Martin R. Berger, Unit of Toxicology and Chemotherapy, German Cancer Research Center, Im Neuenheimer Feld 280, D-69120 Heidelberg, Germany

E-mail: m.berger@dkfz.de

Key words: K-ras mutations, colorectal cancer, colorectal polyp, inconspicuous mucosa, PCR-RFLP

\section{Introduction}

The transformation of normal colonic epithelium to cancer is a multi-step process which is characterized by the accumulation of genetic alterations, e.g. by activating oncogenes and inactivating tumour suppressor genes (1). As previously described, mutations in the K-ras gene contribute at an early stage to the development in the colon tumourigenesis pathway (2-4). The crucial alterations of the K-ras gene which are responsible for malignant transformation are point mutations in codons 12, 13 and 61 (5-7). Despite the fact that these mutations have been known for a considerable time, possible differences between these mutations regarding their potential in cancer progression have not yet been fully elucidated. On a descriptive level, there are different ratios of K-ras codon 12 and 13 mutations in colorectal cancer. The largest study published so far reported a ratio of 3:1 in favour of K-ras codon 12 mutations (8) which is in line with another study (ratio of 3.5:1) (9), whereas others found a relatively higher number of K-ras codon 13 mutations resulting in a ratio of 1.3:1 (10). This variation indicates that the respective prevalence probably depends on the population of the study and thus on different influences resulting from ethnic background and environmental determinants, as e.g. the diet (11). On a functional level, some authors hinted at differences in the metastatic potential of tumours correlated with codon 12 and 13 mutations. Schimanski et al described that although K-ras codon 12 mutations prevailed over codon 13 mutations in tumour tissue (ratio: 6.4:1), a significantly smaller proportion of K-ras codon 13 mutated tumour cells was found in liver biopsies of these patients (ratio: 20:1) (12). Bazan et al described an association between K-ras codon 13 mutations and the presence of lymph node metastases (10). These findings could implicate a different nature of K-ras codon 12 and 13 mutations regarding their spreading from the primary tumour and homing into metastatic target organs such as liver and lymph nodes.

The present study was performed to examine the origin and relative frequency of codon 12 and 13 mutations from a different point of view. Theoretically, K-ras codon 12 mutations could be found more often in tumour tissue because the bases of K-ras codon 12 might be more amenable to damaging events. In that case, a ratio between K-ras codon 12 and 13 
mutations, as present in tumour tissue, should be found from early on, e.g. in polyps and in inconspicuous mucosa tissue. Here, we compared the incidences of both point mutations in inconspicuous mucosa as well as in polyp and carcinoma tissues originating from colon cancer patients. Differences in the relative frequencies of K-ras codon 12 and 13 mutations were found and hint at a similar origin of these lesions but differences in their potential for cancer progression.

\section{Materials and methods}

Patient samples. Tissue samples originated from colorectal carcinoma patients who underwent elective surgery in municipal hospitals of Ludwigshafen and Nürnberg, Germany, after giving their informed consent and after ethical approval of the respective committees. The sampling differed between the two hospitals: mucosa and tumour samples originated from patients of the municipal hospital Ludwigshafen (group I) whereas polyp and tumour samples were collected from patients of the municipal hospital Nürnberg (group II). The groups did not show significant differences in their characteristics and can therefore be presented as one group of patients (Table I).

Mucosa samples were taken from four different sites relative to the respective tumour localisation. The first mucosa sample was collected as a 1-cm-wide circular band, localised $9-10 \mathrm{~cm}$ proximal of the tumour site; the other samples were the size of about $1 \mathrm{~cm}^{2}$ taken $6-7 \mathrm{~cm}$ and $3-4 \mathrm{~cm}$ proximal as well as $2-3 \mathrm{~cm}$ distal of the tumour. Tumour tissue (200-500 mg) was taken from a central part of the respective carcinoma; polyp tissue (100-250 mg) was taken from the centre of large polyps whereas small polyps (below $100 \mathrm{mg}$ ) were used in toto. Only non-necrotic tissue was collected. All samples were snap frozen in liquid nitrogen and stored at $-80^{\circ} \mathrm{C}$ until further examination. From a total sample mass of up to $1063 \mathrm{mg}$ (mucosa), 20-200 mg were subjected to DNA and RNA extraction.

Control samples. Three cell lines, the human leukaemia cell line SKW3, the human mammary carcinoma cell line MDAMB 231 and the human colon carcinoma cell line SW620, were used as controls for PCR-RFLP. SKW3 was wild-type in K-ras codon 12 and 13 and functioned as negative control, whereas SW620 served as positive control for detecting K-ras codon 12 mutations (GGT $\rightarrow$ GAT) and MDA-MB 231 as positive control for K-ras codon 13 mutations (GGC $\rightarrow \mathrm{GAC}$ ). SW620 cells were cultured in Leibowitz L15 medium, SKW3 and MDA-MB 231 in RPMI 1640 medium (10\% FCS, $2 \mathrm{mM}$ L-glutamine) under standard conditions (humidified atmosphere, $5 \% \mathrm{CO}_{2}, \mathrm{~T}: 37^{\circ} \mathrm{C}$ ) and passaged twice weekly to maintain logarithmic growth.

Extraction of DNA. For DNA extraction, tissue samples from colorectal carcinoma patients were subjected to homogenisation and lysis using the Qiagen RNA/DNA Kit (Qiagen, Hilden, Germany). Isolated DNA was measured by spectrophotometry.

Detection of K-ras mutations by RFLP-PCR. The RFLP-PCR consisted of two PCR and two restriction fragment length polymorphism steps and was performed as described before
(12). For the first PCR step, $300 \mathrm{ng}$ of isolated DNA were used and added to a reaction mixture containing oligonucleotide primers Ras A and Ras B $(0.2 \mu \mathrm{M})$, deoxynucleotide triphosphates $(0.2 \mu \mathrm{M}), 1.5 \mathrm{mM} \mathrm{MgCl}_{2}, 1.5 \mathrm{U}$ Red Taq polymerase (Sigma-Aldrich, Steinheim, Germany) and $5 \mu 1$ reaction buffer in a total reaction volume of $50 \mu \mathrm{l}$. All reactions were run in a thermocycler (DNA engine PTC200, MJ Research, Watertown, MA) according to the following protocol: initial denaturation $\left(4 \mathrm{~min}\right.$ at $95^{\circ} \mathrm{C}$ ), followed by 30 cycles of denaturation $\left(1 \mathrm{~min}\right.$ at $\left.94^{\circ} \mathrm{C}\right)$, annealing $(1 \mathrm{~min}$ at $52^{\circ} \mathrm{C}$ ), elongation $\left(2 \mathrm{~min}\right.$ at $\left.72^{\circ} \mathrm{C}\right)$ and final extension $(5 \mathrm{~min}$ at $72^{\circ} \mathrm{C}$ ). For the first restriction in codon $12,10 \mu 1$ of the first PCR reaction were mixed with $1 \mu 1$ restriction enzyme BstXI (MBI, Fermentas, St. Leon-Roth, Germany) and $2 \mu 1$ of buffer (10X), brought to a total volume of $20 \mu \mathrm{l}$ by adding $\mathrm{ddH}_{2} \mathrm{O}$ and incubated at $55^{\circ} \mathrm{C}$ for $18 \mathrm{~h}$.

The second PCR reaction was performed using $2 \mu \mathrm{l}$ of the first restriction assay as described above for the first PCR except that primer Ras C was used instead of primer Ras B which created an additional cleavage site for BstXI in both mutant and wild-type K-ras amplicons serving as control for enzyme function. The second restriction step was performed in analogy to the first restriction. For codon 13, the protocol was similar except that the restriction enzyme XcmI (New England BioLabs, Schwalbach, Germany) was used and that all samples were incubated at $37^{\circ} \mathrm{C}$ for $18 \mathrm{~h}$. A $12 \mu \mathrm{l}$ aliquot of each reaction was analysed by electrophoresis on an $8 \%$ polyacrylamide gel (Roth, Karlsruhe, Germany), stained with ethidium bromide for $3 \mathrm{~min}$ and examined under UV light using a video densitometer (Herolab, Wiesloch, Germany).

DNA sequencing. The presence of $\mathrm{K}$-ras mutations was confirmed by cycle sequencing. For this purpose, the mutated amplicons found by RFLP-PCR were excised from a $3 \%$ agarose gel and subjected to purification with Qia Quick gel extraction kit (Qiagen, Hilden, Germany) according to the manufacturer's recommendations. Sequencing reactions were then performed with the respective sequencing primer and the 3'Big Dye Terminator Cycle Sequencing Ready Reaction kit (ABI, Weiterstadt, Germany) according to the manufacturer's instructions (12).

Statistical analysis. The mean age of patients and the respective standard deviation was calculated for all subgroups. In addition, the non-parametric Wilcoxon test was used to compare the age of the respective subgroups. The contingency $\chi^{2}$ test was applied to compare all other patient and tumour characteristics. P-values $<0.05$ were regarded as significant.

\section{Results}

Patient and tumour characteristics. The characteristics of all patients with colorectal tumours are given in Table I. The age of these patients ranged from $48-88$ years. The mean age of male patients did not differ significantly from that of female patients regardless of the contributing hospital.

Most of the tumours were found in the rectum and sigmoid of the large bowel (39.3\% and 22.6\%) followed by tumours detected in the ascending colon (16.6\%). Out of 84 tumours, 79 were characterized histologically as adenocarcinomas whereas the remaining 5 were found to be adenomas. No 
Table I. Patient and tumour characteristics specified by gender.

\begin{tabular}{|c|c|c|c|}
\hline & Female $(\%)$ & Male (\%) & Total $(\%)$ \\
\hline \multicolumn{4}{|l|}{ Patients (group I) } \\
\hline No. & 14 & 22 & 36 \\
\hline Mean age $\pm \mathrm{SD}^{\mathrm{b}}$ & $67.8 \pm 11.9$ & $64.6 \pm 7.2$ & $65.8 \pm 9.3$ \\
\hline \multicolumn{4}{|l|}{ Patients (group II) } \\
\hline No. & 20 & 28 & 48 \\
\hline Mean age \pm SD & $70.4 \pm 8.5$ & $66.8 \pm 10.3$ & $68.3 \pm 9.7$ \\
\hline \multicolumn{4}{|l|}{ All patients } \\
\hline No. & 34 & 50 & 84 \\
\hline Mean age \pm SD & $69.3 \pm 10.0$ & $65.8 \pm 9.0$ & $67.2 \pm 9.5$ \\
\hline \multicolumn{4}{|l|}{ Colorectal segment } \\
\hline Coecum & $2(5.9)$ & $5(10.0)$ & $7(8.3)$ \\
\hline Ascending colon & $7(20.6)$ & $7(14.0)$ & $14(16.6)$ \\
\hline Transverse colon & $4(11.8)$ & $4(8.0)$ & $8 \quad(9.5)$ \\
\hline Descending colon & $1 \quad(2.9)$ & $2(4.0)$ & $3(3.6)$ \\
\hline Sigmoid & $8(23.5)$ & $11(22.0)$ & $19(22.6)$ \\
\hline Rectum & $12(35.3)$ & $21(42.0)$ & $33(39.3)$ \\
\hline \multicolumn{4}{|l|}{ Histology } \\
\hline Adenoma & 2 & 3 & 5 \\
\hline Adenocarcinoma & 32 & 47 & 79 \\
\hline \multicolumn{4}{|l|}{$\begin{array}{l}\text { pTNM classification } \\
\text { (adenocarcinoma) }\end{array}$} \\
\hline $\mathrm{T} 1$ & $1(3.1)$ & $2(4.3)$ & $3(3.8)$ \\
\hline $\mathrm{T} 2$ & $12(37.5)$ & $15(31.9)$ & $27(34.2)$ \\
\hline T3 & $17(53.1)$ & $26(55.3)$ & $43(54.4)$ \\
\hline $\mathrm{T} 4$ & $2(6.3)$ & $4 \quad(8.5)$ & $6 \quad(7.6)$ \\
\hline No & $17(53.1)$ & $25(53.2)$ & $42(53.2)$ \\
\hline N1 & $10(31.3)$ & $10(21.3)$ & $20(25.3)$ \\
\hline $\mathrm{N} 2$ & $5(15.6)$ & $12(25.5)$ & $17(21.5)$ \\
\hline M0 & $30(93.8)$ & $38(80.9)$ & $68(86.1)$ \\
\hline M1 & $2(6.3)$ & $9(19.1)$ & $11(13.9)$ \\
\hline \multicolumn{4}{|l|}{ UICC } \\
\hline I & $9(28.1)$ & $13(27.7)$ & $22(27.8)$ \\
\hline II & $9(28.1)$ & $11(23.4)$ & $20(25.3)$ \\
\hline III & $13(40.6)$ & $14(29.8)$ & $27(34.2)$ \\
\hline IV & 1 & $9(19.1)$ & $10(12.7)$ \\
\hline \multicolumn{4}{|l|}{ Grading } \\
\hline G1 & $1 \quad(3.1)$ & 0 & 1 (1.3) \\
\hline $\mathrm{G} 2$ & $27(84.4)$ & $31(66.0)$ & $58(73.4)$ \\
\hline G3 & $4(12.5)$ & $16(34.0)$ & $20(25.3)$ \\
\hline G4 & 0 & 0 & 0 \\
\hline L0 & $9(28.1)$ & $15(31.9)$ & $24(30.4)$ \\
\hline L1 & $23(71.9)$ & $32(68.1)$ & 55 (69.6) \\
\hline V0 & $28(87.5)$ & $35(74.5)$ & $63(79.7)$ \\
\hline V1 & $4(12.5)$ & $12(25.5)$ & $16(20.3)$ \\
\hline R0 & 31 (96.9) & $41(87.2)$ & $72(91.1)$ \\
\hline $\mathrm{R} 1$ & $1 \quad(3.1)$ & 0 & 1 (1.3) \\
\hline $\mathrm{R} 2$ & 0 & $6(12.8)$ & $6 \quad(7.6)$ \\
\hline
\end{tabular}

${ }^{a}$ Years; ${ }^{b}$ standard deviation. 
Table II. Synopsis of K-ras mutations in mucosa, polyp and tumour tissue.

\begin{tabular}{llllllll}
\hline & & & & \multicolumn{3}{c}{ No of Ras-mutated samples by PCR-RFLP assay } \\
(by sequencing)
\end{tabular}

${ }^{a}$ Two samples harboured a codon 12 (C12) plus a codon 13 (C13) mutation; ${ }^{\text {o }}$ one sample harboured a codon 12 (C12) plus a codon 13 (C13) mutation; ${ }^{\mathrm{c}} \mathrm{p}<0.004\left(\chi^{2}\right) ;{ }^{\mathrm{d}} \mathrm{p}=0.053\left(\chi^{2}\right)$.

a

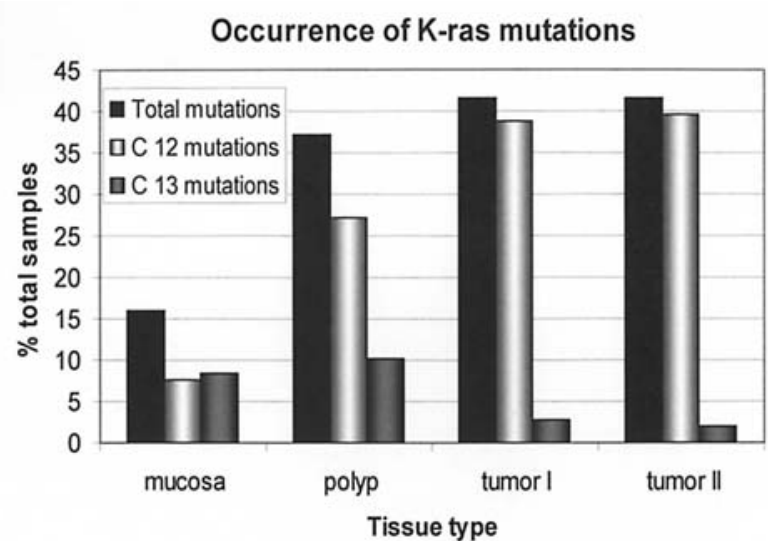

b

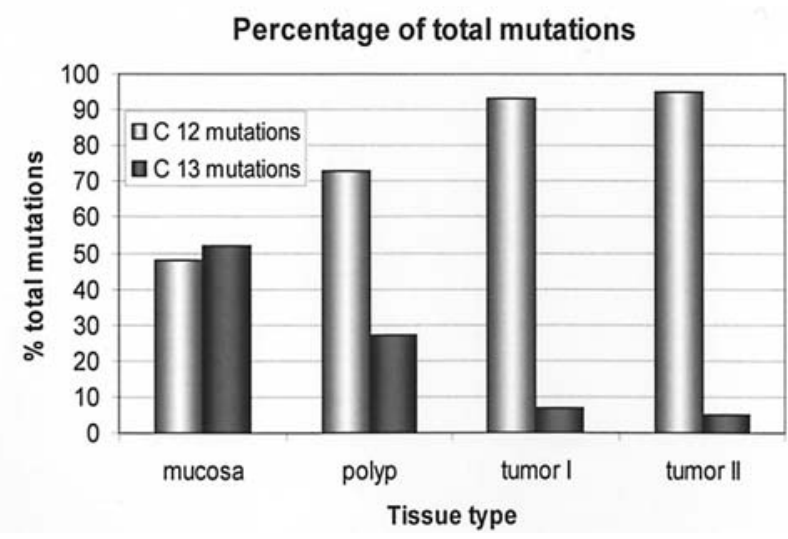

Figure 1. The number of K-ras mutations is expressed as percent of the total number of tissue samples (A) or as percent of the total mutation number for K-ras codon 12 and 13 mutations (B).

gender related difference was detected regarding the site or histology of the tumours.

The majority of carcinomas was classified as tumour stages T3 (54.4\%) and T2 (34.2\%). Most tumours did not disseminate into regional lymph nodes (N0;53.2\%). The remaining tumours showed nodal involvement and were therefore classified as N1 (25.3\%) and N2 (21.5\%). Distant metastasis (M1) was detected in $13.9 \%$ of all tumours. No significant gender differences were observed.

The distribution of all tumours according to the UICC status did not show major imbalances. Most tumours were ranked as UICC III (34.2\%), followed by UICC I, II and IV $(27.8 \%, 25.3 \%$ and $12.7 \%)$. No residual tumour mass was found in the vast majority of the cases $(91.1 \%)$, the remaining patients with residual tumour disease were classified as R2 (7.6\%) or R1 (1.3\%).

Histologically, the majority of all tumours were graded as G2 (73.4\%) and G3 (25.3\%). Examination of the surrounding tumour tissue showed that only a minority of tumours $(20.3 \%)$ had eroded venous vessels (V1) whereas a larger number of tumours $(69.6 \%)$ presented with lymphatic vessel invasion (L1).

Detection of $K$-ras mutations in tissues from colorectal carcinoma patients. Table II shows a synopsis of K-ras mutations in mucosa, polyp and tumour tissues. Tumour and mucosa tissues were taken from 36 patients belonging to group I. Due to four collection sites the study included 144 mucosa samples. A total of 21 mucosa samples obtained from 11 patients (30.6\% of all patients) were mutated in codons 12 and 13 , which corresponds to $14.6 \%$ of all mucosa samples. Out of 23 mutations in total, $11(47.8 \%)$ were codon 12 and $12(52.2 \%)$ were codon 13 mutations (Fig. 1). Two samples carried both, a codon 12 and a codon 13 mutation. Ten of 11 mutations in codon 12 and two of 12 codon 13 mutations could be confirmed by cycle sequencing. The ratio of codon 12 and 13 mutations found by PCR-RFLP was $0.9: 1$, whereas this ratio was 5.5:1 if only those mutations were counted that had been verified by sequencing.

Out of 36 tumour samples, 13 samples (36.1\%) bore mutations in codon 12 or 13 , except for one that carried a mutation in both codons. Cycle sequencing confirmed 13 of the 14 codon 12 mutations as well as the only codon 13 mutation in tumour tissue. The ratio of codon 12 and 13 mutations found by PCR-RFLP was 14:1; the ratio of the samples confirmed by sequencing was $13: 1$. When comparing the ratio of codon 12 and 13 mutations in mucosa and tumour tissue, a significant difference was found $\left(\mathrm{p}=0.004, \chi^{2}\right)$ between a balanced prevalence in mucosa tissue and a predominant prevalence of codon 12 mutations in tumour tissue. 
Table III. Relative frequency of mutated sequences.

\begin{tabular}{|c|c|c|c|c|c|c|c|c|c|}
\hline & \multirow{2}{*}{$\begin{array}{c}\text { Total no. } \\
\text { of mutations }\end{array}$} & \multicolumn{5}{|c|}{ Codon $12(w t=$ GGT $)$} & \multicolumn{3}{|c|}{ Codon $13(\mathrm{wt}=\mathrm{GGC})$} \\
\hline & & GAT & GTT & GCT & AGT & TGT & GAC & GTC & GCC \\
\hline Mucosa & 13 & $9^{a}$ & $2^{\mathrm{b}}$ & - & - & - & 1 & 1 & - \\
\hline Tumour I & 14 & 6 & 6 & 1 & - & - & - & - & 1 \\
\hline Polyp & $25^{\mathrm{c}}$ & 10 & 6 & 2 & 1 & - & 6 & - & - \\
\hline Tumour II & $22^{\mathrm{d}}$ & 7 & 9 & 1 & 3 & 1 & 1 & - & - \\
\hline
\end{tabular}

${ }^{a}$ Nine mutated mucosa samples originating from 6 patients; ${ }^{b}$ two mutated mucosa samples originating from 1 patient; ${ }^{c}$ three samples carried 2 different mutations in codon 12; d two samples carried 2 different mutations in codon 12.

No mucosa but polyp and tumour tissue samples were taken from group II patients. From 59 polyps collected in total, $18(30.5 \%)$ bore a codon 12 or 13 mutation whereas two polyps (3.4\%) carried both, a codon 12 and 13 mutation. All 16 codon 12 mutations and six codon 13 mutations were confirmed by cycle sequencing. Out of 48 tumour samples from group II patients, $20(41.7 \%)$ carried mutations in K-ras, $19(95 \%)$ of which were found in codon 12 and one $(5 \%)$ in codon 13. All of them were confirmed by cycle sequencing. The ratio of codon 12 and 13 mutations found by PCR-RFLP and cycle sequencing was 2.7:1 for polyps and 19:1 for carcinomas. The difference in these ratios was almost significant $\left(\mathrm{p}=0.053, \chi^{2}\right)$.

The relative frequency of mutations found in tissue of all patients is shown in Table III. Most of the mutations in mucosa tissue were transitions from $\mathrm{G} \rightarrow \mathrm{A}$ in base 2 of codon 12 (9 of 11 codon 12 mutations). Tumour tissue, on the other hand, showed a balanced appearance of $\mathrm{G} \rightarrow \mathrm{A}$ transitions and $\mathrm{G} \rightarrow \mathrm{T}$ transversions in base 2 ( 6 of 13 codon 12 mutations respectively). The two codon 13 mutations that were confirmed by cycle sequencing were a $G \rightarrow A$ transition and a $G \rightarrow T$ transversion. The single codon 13 mutation found in tumour tissue in group I was a $\mathrm{G} \rightarrow \mathrm{C}$ transversion. Nineteen of the 25 K-ras mutations found in polyp tissue were related to codon 12 and six to codon 13. Most of these mutations were $G \rightarrow A$ transitions in base 2 of K-ras codon 12 (10 of 19), followed by $\mathrm{G} \rightarrow \mathrm{T}$ transversions ( 6 of 19$)$. There was one $\mathrm{G} \rightarrow \mathrm{A}$ transition found in base 1 of codon 12 . In the respective tumour tissue, 21 mutations were found in codon 12 and one in codon 13 . Here, the $\mathrm{G} \rightarrow \mathrm{T}$ transversion prevailed over the $\mathrm{G} \rightarrow \mathrm{A}$ transition in base 2 of codon 12 ( 9 of 21 versus 7 of 21 codon 12 mutations). Moreover, mutations in base 1 appeared more frequently than in the other tissues (10). Three of those were $\mathrm{G} \rightarrow \mathrm{A}$ transitions; one was a $\mathrm{G} \rightarrow \mathrm{T}$ transversion. Interestingly, three polyp samples and two tumour samples carried two different codon 12 mutations concomitantly.

Table IVA shows a complete list of mutations in mucosa or the respective tumour tissue, thus giving a relation of mutated and wild-type tissue originating from the same patient. Regarding the collection site of the mutated mucosa tissue, most mutations were found distal of the tumour (five of eleven codon 12, and four of twelve codon 13 mutations). In the remaining collection sites the frequency was distributed equally for codon 12 mutations (two mutated samples in each site), whereas the frequency was shifted towards the most proximal site for codon 13 mutations (four mutated samples in collection site 1 , three in site 2 and one in site 3 ).

A K-ras mutation was found in 22 of 36 patients. Of these, 8 patients harboured a mutation in inconspicuous mucosa tissue without a concomitant mutation in the respective tumour sample. Eleven patients bore K-ras mutations in their tumour samples only. Three patients carried both K-ras mutations in mucosa and tumour tissue samples, but none of these mutations matched the respective counterpart.

Table IVB shows the corresponding list of mutations found in polyp and the respective tumour tissues of group II patients. A K-ras mutation was found in 34 of 48 patients. Of these, 14 patients carried a mutation in a polyp but not in the respective tumour sample. The same number of patients carried a K-ras mutation in their tumour tissue with the corresponding polyp tissue being wild-type. Six patients bore both, a mutation in polyp and tumour tissue, but the sequence of these mutations was identical in three cases only.

\section{Discussion}

This study investigated the ratio of K-ras codon 12 and 13 mutations in normal mucosa, polyp and carcinoma tissues in order to compare the prevalence of these lesions in regard to tumour development and progression. Multiple samples of apparently normal mucosa tissue (group I) and of polyp tissue (group II) were compared with a sample from concomitantly growing colorectal carcinoma. In variation with previous, less detailed investigations on mucosa tissue $(12,13)$, a higher percentage of mucosa samples (14.6\%; corresponding to $30.5 \%$ of all patients) were found to harbour a K-ras mutation in their inconspicuous mucosa. More remarkable, however, is the finding that there was an even distribution between K-ras codon 12 and 13 mutations. The PCR-RFLP ratio of codon 12 and 13 mutations in mucosa (0.9:1; codon 12 : codon 13$)$ demonstrates that there is no fundamental difference in the induction of K-ras codon 12 and 13 mutations. This finding might be questioned due to the fact that distinctly less codon 13 than codon 12 mutations could be confirmed by sequencing. Confirmation by sequencing, however, depends on the relative frequency of the mutated clones in wild-type tissue. According 
Table IV. A, Complete list of mutations found in mucosa and tumour tissue.

\begin{tabular}{|c|c|c|c|c|c|c|c|c|c|}
\hline \multicolumn{5}{|c|}{ Patient characteristics group I } & \multicolumn{2}{|c|}{ Mucosa } & \multicolumn{3}{|c|}{ Tumour $^{\mathrm{c}}$} \\
\hline No. & Gender & Age & $\mathrm{T}$ & UICC & Codon 12 & Codon 13 & Codon 12 & Codon 13 & Relation \\
\hline 1 & $\mathrm{M}$ & 76 & 3 & III & GAT $(s 4)^{a}$ & RFLP pos ${ }^{\mathrm{b}}(\mathrm{s} 2)$ & wt & $\mathrm{wt}$ & $\diamond^{e}$ \\
\hline 2 & M & 65 & 3 & II & wt & RFLP pos (s4) & wt & wt & $\nabla^{e}$ \\
\hline 5 & $\mathrm{~F}$ & 45 & - & - & wt & wt & GTT & $w t^{d}$ & $* *^{\mathrm{f}}$ \\
\hline 8 & $\mathrm{~F}$ & 85 & 3 & III & wt & wt & GTT & wt & $*^{\mathrm{f}}$ \\
\hline 9 & $\mathrm{~F}$ & 75 & 3 & II & wt & wt & RFLP pos & $\mathrm{wt}$ & $* *^{\mathrm{f}}$ \\
\hline 10 & $\mathrm{M}$ & 51 & 3 & III & $\begin{array}{l}\text { GAT }(\mathrm{s} 2+4) / \\
\text { GTT }(\mathrm{s} 3+4)\end{array}$ & wt & wt & wt & $\nabla^{e}$ \\
\hline 11 & M & 72 & 4 & II & wt & RFLP pos (s1) & GTT & wt & $\mathbf{\square}^{\mathrm{g}}$ \\
\hline 12 & $\mathrm{~F}$ & 86 & - & - & wt & wt & GAT & $w t^{d}$ & $*^{\mathrm{f}}$ \\
\hline 14 & $\mathrm{~F}$ & 59 & 1 & III & wt & wt & GAT & wt & $*^{f}$ \\
\hline 16 & $\mathrm{~F}$ & 58 & 2 & I & wt & wt & GAT & GCC & $*^{\mathrm{f}}$ \\
\hline 20 & M & 50 & 3 & II & GAT (s1+3) & wt & wt & wt & $\diamond^{e}$ \\
\hline 21 & $\mathrm{~F}$ & 51 & 3 & III & wt & wt & GAT & wt & $*^{\mathrm{f}}$ \\
\hline 22 & $\mathrm{~F}$ & 69 & 2 & I & GAT (s4) & wt & wt & $\mathrm{wt}$ & $\diamond^{\mathrm{e}}$ \\
\hline 23 & $\mathrm{M}$ & 65 & 1 & I & wt & RFLP pos (s4) & wt & wt & $\diamond^{\mathrm{e}}$ \\
\hline 24 & M & 70 & 3 & IV & $\mathrm{wt}$ & $\mathrm{wt}$ & GAT & $\mathrm{wt}$ & $*^{\mathrm{f}}$ \\
\hline 25 & $\mathrm{~F}$ & 71 & 2 & I & wt & wt & GAT & wt & $*^{\mathrm{f}}$ \\
\hline 28 & M & 76 & 4 & IV & $\mathrm{wt}$ & wt & GTT & $\mathrm{wt}$ & $* *^{\mathrm{f}}$ \\
\hline 29 & $\mathrm{~F}$ & 68 & 2 & I & wt & RFLP pos (s4) & GTT & $\mathrm{wt}$ & $\square^{\mathrm{g}}$ \\
\hline 30 & $\mathrm{~F}$ & 72 & 3 & II & GAT (s4) & RFLP pos (s1) & GTT & $\mathrm{wt}$ & $\mathbf{n}^{\mathrm{g}}$ \\
\hline 31 & $\mathrm{M}$ & 59 & 3 & IV & wt & wt & GCT & wt & $*^{\mathrm{f}}$ \\
\hline 34 & M & 57 & 2 & I & $\mathrm{wt}$ & $\begin{array}{l}\text { RFLP pos } \\
(\mathrm{s} 1+2+3+4)\end{array}$ & $\mathrm{wt}$ & $\mathrm{wt}$ & $\diamond^{e}$ \\
\hline 36 & M & 57 & 3 & IV & GAT (s1+2) & $\begin{array}{l}\text { GAC (s2)/ } \\
\text { GTC (s1) }\end{array}$ & $\mathrm{wt}$ & wt & $\diamond^{e}$ \\
\hline
\end{tabular}

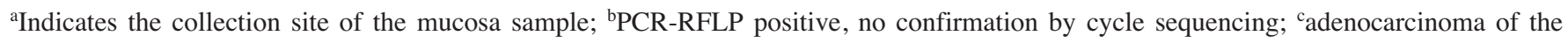
colorectum if not specified differently; ${ }^{\mathrm{d}}$ adenoma of the colorectum; ${ }^{\mathrm{e}}$ mutated mucosa tissue but wild-type tumour tissue was found in 8 patients; ${ }^{\mathrm{f}}$ mutated tumour tissue but wild-type mucosa tissue was found in 11 patients; ${ }^{\mathrm{g}}$ mutated mucosa and tumour tissue was found in 3 patients.

B, Complete list of mutations found in polyp and tumour tissue.

\begin{tabular}{|c|c|c|c|c|c|c|c|c|c|}
\hline \multirow[b]{2}{*}{ No. } & \multicolumn{4}{|c|}{ Patient characteristics group II } & \multicolumn{2}{|c|}{ Polyp } & \multicolumn{3}{|c|}{ Tumour ${ }^{\mathrm{a}}$} \\
\hline & Gender & Age & $\mathrm{T}$ & UICC & Codon 12 & Codon 13 & Codon 12 & Codon 13 & Relation \\
\hline 1 & M & 70 & 3 & III & GAT & wt & wt & wt & $\Delta^{c}$ \\
\hline 3 & M & 81 & - & - & wt & GAC & wt & $w t^{b}$ & $\Delta^{\mathrm{b}}$ \\
\hline 4 & M & 59 & 3 & II & wt & wt & GTT & wt & 冰 $\mathrm{d}$ \\
\hline 5 & M & 58 & 3 & III & GAT & $\mathrm{wt}$ & $\mathrm{wt}$ & wt & $\diamond^{c}$ \\
\hline 7 & $\mathrm{~F}$ & 56 & 3 & III & GTT/GCT & wt & wt & wt & $\diamond^{c}$ \\
\hline 9 & $\mathrm{~F}$ & 62 & 2 & I & wt & wt & wt & GAC & 冰d \\
\hline 10 & $\mathrm{~F}$ & 81 & 3 & III & wt & GAC & $\mathrm{wt}$ & $\mathrm{wt}$ & $\diamond^{c}$ \\
\hline 11 & M & 57 & 3 & IV & wt & wt & GAT & wt & 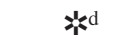 \\
\hline 13 & M & 66 & 3 & III & GCT & GAC & $\mathrm{wt}$ & wt & $\diamond^{c}$ \\
\hline 14 & M & 48 & 3 & IV & GAT & wt & wt & wt & $\diamond^{c}$ \\
\hline 15 & M & 65 & 2 & $\mathrm{I}$ & GAT/GTT & GAC & GTT & wt & $\mathbf{m}^{\mathrm{e}}$ \\
\hline 15 & M & 65 & 2 & I & wt & GAC & GTT & wt & $\mathbf{m}^{\mathrm{e}}$ \\
\hline 16 & $\mathrm{~F}$ & 75 & 3 & III & GTT & wt & TGT & wt & $\mathbf{a}^{\mathrm{e}}$ \\
\hline 17 & $\mathrm{~F}$ & 80 & 3 & III & GTT/GAT & wt & wt & wt & $\diamond^{c}$ \\
\hline
\end{tabular}


Table IV. B, Continued.

\begin{tabular}{|c|c|c|c|c|c|c|c|c|c|}
\hline \multicolumn{5}{|c|}{ Patient characteristics group II } & \multicolumn{2}{|c|}{ Polyp } & \multicolumn{3}{|c|}{ Tumour ${ }^{\mathrm{a}}$} \\
\hline No. & Gender & Age & $\mathrm{T}$ & UICC & Codon 12 & Codon 13 & Codon 12 & Codon 13 & Relation \\
\hline 20 & M & 57 & 3 & II & wt & wt & GAT & wt & 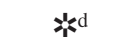 \\
\hline 22 & $\mathrm{~F}$ & 79 & 2 & I & AGT & wt & $\mathrm{wt}$ & wt & $\Delta^{c}$ \\
\hline 23 & M & 72 & 2 & I & wt & wt & GTT & wt & 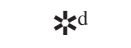 \\
\hline 24 & M & 80 & 3 & III & GAT & wt & GAT & wt & $\mathbf{a}^{\mathrm{e}}$ \\
\hline 25 & $\mathrm{~F}$ & 69 & 3 & III & wt & $\mathrm{wt}$ & GTT & wt & $*^{d}$ \\
\hline 27 & M & 55 & 1 & I & GAT & $\mathrm{wt}$ & wt & wt & $\diamond^{c}$ \\
\hline 28 & M & 72 & 3 & IV & $\mathrm{wt}$ & wt & GTT & wt & $2^{d}$ \\
\hline 29 & M & 48 & 3 & II & GTT & wt & GTT & wt & $\mathbf{q}^{\mathrm{e}}$ \\
\hline 30 & $\mathrm{~F}$ & 71 & 3 & II & GTT & wt & wt & wt & $\diamond^{c}$ \\
\hline 32 & M & 80 & 3 & III & wt & wt & AGT & wt & 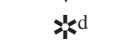 \\
\hline 34 & $\mathrm{~F}$ & 59 & 2 & I & wt & wt & AGT/GAT & wt & 将 \\
\hline 36 & M & 61 & 2 & III & GAT & wt & GCT & wt & $\mathbf{a}^{\mathrm{e}}$ \\
\hline 37 & $\mathrm{~F}$ & 62 & 2 & I & GAT & $\mathrm{wt}$ & $\mathrm{wt}$ & wt & $\diamond^{c}$ \\
\hline 39 & M & 76 & 2 & I & wt & wt & GTT & wt & $2^{d}$ \\
\hline 40 & $\mathrm{~F}$ & 65 & 3 & III & GAT & wt & wt & wt & $\diamond^{\mathrm{c}}$ \\
\hline 42 & $\mathrm{~F}$ & 61 & 4 & II & wt & wt & GAT & wt & 冰d \\
\hline 43 & M & 73 & 2 & I & wt & wt & AGT/GAT & wt & 冰d \\
\hline 45 & M & 88 & 3 & II & wt & GAC & wt & wt & $\diamond^{c}$ \\
\hline 46 & M & 63 & 4 & II & wt & wt & GAT & wt & 冰d \\
\hline 49 & $\mathrm{~F}$ & 75 & 3 & II & wt & wt & GTT & wt & 冰 \\
\hline
\end{tabular}

${ }^{a}$ Adenocarcinoma of the colorectum if not specified differently; badenoma of the colorectum; ${ }^{c}$ mutated polyp tissue but wild-type tumour tissue was found in 14 patients; ${ }^{\mathrm{d}}$ mutated tumour tissue but wild-type polyp tissue was found in 14 patients; ${ }^{\mathrm{e}}$ mutated polyp and tumour tissue was found in 6 patients.

to dilution experiments with K-ras mutated and wild-type cells, only ratios ranging up to $1: 10^{4}$ can reliably be found by sequencing. Therefore, the results of the PCR-RFLP assay, which detects dilutions of $1: 10^{6}$ mutated in wild-type cells, should not be neglected.

The PCR-RFLP ratio of about 1:1 was increased in polyp tissue (2.7:1; codon 12 : codon 13$)$ and even more drastically in samples from the respective carcinomas (14:1 and 19:1; codon 12 : codon $13 ; \mathrm{p}<0.004$ versus mucosa and $\mathrm{p}=0.053$ versus polyps). Comparing the percentage of patients harbouring a K-ras mutation in their mucosa with the respective percentages found in polyps $(41.7 \%)$ or carcinomas $(42 \%)$, the latter ratios of mutations were only slightly elevated. Instead of a fundamental difference in their induction, it seems more likely that the relative prevalence of K-ras codon 12 and 13 mutations changes with tumour progression. The altered occurrence of the two types of mutation might be explained as follows.

Stable transfectants of NIH3T3 fibroblasts expressing a plasmid containing K-ras mutated in codon 12 or codon 13 showed distinctly less apoptotic cell death in case of the former as opposed to the latter mutant (14). This difference has been associated with a more aggressive phenotype of K-ras codon 12 mutated cells. In correlation with this behaviour, K-ras codon 12 mutated NIH3T3 fibroblasts showed a greatly increased glycolysis whereas K-ras codon 13 mutated cells showed only a modest increase in this pathway (15). Besides these cellular properties, clinical observations hint to functional differences between the two K-ras mutants, as well. Bazan et al described an association between K-ras codon 13 mutations and the presence of lymph node metastases (10). This finding has been validated on a different level as well. Conzelmann et al described a differential pattern of colorectal tumour cell dissemination, pending on the K-ras mutation status (16). K-ras codon 13 mutated tumour cells spread significantly more often into lymph nodes than K-ras codon 12 mutated tumour cells, which were found more often in the liver. In line with this observation, Schimanski et al described that although K-ras codon 12 mutations prevailed over codon 13 mutations in tumour tissue, a significantly smaller proportion of K-ras codon 13 mutated tumour cells was found in liver biopsies of these patients (12). Taken together, these data indicate a clear difference in function and metastatic dissemination associated with either codon 12 or codon 13 mutations of the K-ras gene.

Furthermore, the spectrum of mutations found in mucosa tissue shows a clear predominance of $\mathrm{G}: \mathrm{C} \rightarrow \mathrm{A}: \mathrm{T}$ transitions in both, codon 12 and 13 mutations in concordance with other studies $(13,17)$. For codon 12 , this clear predominance is lost in neoplastic tissues. Instead, $\mathrm{G}: \mathrm{C} \rightarrow \mathrm{T}: \mathrm{A}$ transversions show a 
similar prevalence. This indicates a greater benefit in terms of neoplastic growth resulting from the latter as compared to the former point mutation. The greater benefit might be related to the formation of a more stable complex of G12V Ras (codon 12:GTT) as compared to G12D Ras (codon 12:GAT) with GTP, thus causing a more constant oncogenic signal (18).

Reasons for the $\mathrm{G}: \mathrm{C} \rightarrow \mathrm{A}: \mathrm{T}$ transition mutation include the formation of guanine adducts at the transcribed strand, leading to mispairing with thymine, as well as deamination of cytosine in the coding strand, which leads to uracil mispairing with adenine (19-21). In addition, formation of $1, \mathrm{~N}^{2}$-ethenoguanine or oxidation of guanine can direct mis-incorporation of thymine, which would explain the transversion mutation $(\mathrm{G}: \mathrm{C} \rightarrow \mathrm{T}: \mathrm{A})(22,23)$. These data show that the balanced induction of K-ras codon 12 and 13 mutations cannot be attributed to a specific carcinogen.

In summary, during the neoplastic process K-ras codon 12 and 13 mutations are induced at a similar ratio. The change in ratio shows that after balanced induction K-ras codon 12 mutations increase in frequency relative to K-ras codon 13 mutations during tumour progression. This is another hint to the greater aggressive potential of K-ras codon 12 mutations when compared with codon 13 mutations.

\section{Acknowledgements}

This work was supported by the Dr Hans and Dr Elisabeth Birkner Stiftung.

\section{References}

1. Bishop JM: Molecular themes in oncogenesis. Cell 64: 235-248, 1991.

2. Bos JL, Fearon ER, Hamilton SR, et al: Prevalence of ras gene mutations in human colorectal cancers. Nature 327: 293-297, 1987.

3. Vogelstein B, Fearon ER, Hamilton SR, et al: Genetic alterations during colorectal-tumor development. N Engl J Med 319: 525-532, 1988 .

4. Fearon ER and Vogelstein B: A genetic model for colorectal tumorigenesis. Cell 61: 759-767, 1990.

5. Kiaris $\mathrm{H}$ and Spandidos DA: Mutations of ras genes in human tumours (Review). Int J Oncol 7: 413-421, 1995.

6. Finkelstein SD, Sayegh R, Bakker A and Swalsky P: Determination of tumor aggressiveness in colorectal cancer by K-ras-2 analysis. Arch Surg 128: 526-531, 1993.

7. Brink M, De Goeij AF, Weijenberg MP, et al: K-ras oncogene mutations in sporadic colorectal cancer in The Netherlands Cohort Study. Carcinogenesis 24: 703-710, 2003.

8. Andreyev HJ, Norman AR, Cunningham D, et al: Kirsten ras mutations in patients with colorectal cancer: the 'RASCAL II' study. Br J Cancer 85: 692-696, 2001.
9. Samowitz WS, Curtin K, Schaffer D, Robertson M, Leppert M and Slattery ML: Relationship of Ki-ras mutations in colon cancers to tumor location, stage, and survival: a populationbased study. Cancer Epidemiol Biomarkers Prev 9: 1193-1197, 2000.

10. Bazan V, Migliavacca M, Zanna I, et al: Specific codon 13 K-ras mutations are predictive of clinical outcome in colorectal cancer patients, whereas codon $12 \mathrm{~K}$-ras mutations are associated with mucinous histotype. Ann Oncol 13: 1438-1446, 2002.

11. Slattery ML, Anderson K, Curtin K, et al: Lifestyle factors and Ki-ras mutations in colon cancer tumors. Mutat Res 483: 73-81, 2001.

12. Schimanski CC, Linnemann U and Berger MR: Sensitive detection of K-ras mutations augments diagnosis of colorectal cancer metastases in the liver. Cancer Res 59: 5169-5175, 1999.

13. Dieterle CP, Conzelmann M, Linnemann U and Berger MR: Detection of isolated tumor cells by polymerase chain reactionrestriction fragment length polymorphism for K-ras mutations in tissue samples of 199 colorectal cancer patients. Clin Cancer Res 10: 641-650, 2004.

14. Guerrero S, Casanova I, Farre L, Mazo A, Capella G and Mangues R: K-ras codon 12 mutation induces higher level of resistance to apoptosis and predisposition to anchorageindependent growth than codon 13 mutation or proto-oncogene overexpression. Cancer Res 60: 6750-6756, 2000.

15. Vizan P, Boros LG, Figueras A, et al: K-ras codon-specific mutations produce distinctive metabolic phenotypes in NIH3T3 mice (corrected) fibroblasts. Cancer Res 65: 5512-5515, 2005.

16. Conzelmann M, Linnemann U and Berger MR: K-ras codon 12 and 13 mutations are correlated with differential patterns of tumor cell dissemination in colorectal cancer patients. Int J Oncol 24: 1537-1544, 2004.

17. Andreyev HJ, Norman AR, Cunningham D, Oates JR and Clarke PA: Kirsten ras mutations in patients with colorectal cancer: the multicenter 'RASCAL' study. J Natl Cancer Inst 90: 675-684, 1998.

18. Al-Mulla F, Milner-White EJ, Going JJ and Birnie GD: Structural differences between valine-12 and aspartate-12 Ras proteins may modify carcinoma aggression. J Pathol 187: 433-438, 1999.

19. Greenblatt MS, Bennett WP, Hollstein M and Harris CC: Mutations in the p53 tumor suppressor gene: clues to cancer etiology and molecular pathogenesis. Cancer Res 54: 4855-4878, 1994.

20. Morinello EJ, Koc H, Ranasinghe A and Swenberg JA: Differential induction of N(2),3-ethenoguanine in rat brain and liver after exposure to vinyl chloride. Cancer Res 62: 5183-5188, 2002.

21. Qi J, Zhu YQ, Huang MF and Yang D: Hypermethylation of CpG island in O6-methylguanine-DNA methyltransferase gene was associated with $\mathrm{K}$-ras $\mathrm{G}$ to A mutation in colorectal tumor. World J Gastroenterol 11: 2022-2025, 2005.

22. Shu J, Schellhorn HE and Murphy TM: Stationary phaseinduction of $\mathrm{G} \rightarrow \mathrm{T}$ mutations in Escherichia coli. Mutat Res (Epub ahead of print) doi:10.1016/ j.mrfmmm.2005.12.015.

23. Barbin A: Etheno-adduct-forming chemicals: from mutagenicity testing to tumor mutation spectra. Mutat Res 462: 55-69, 2000. 